\title{
Post-ictal psychosis after right temporal lobectomy
}

\author{
R Manchanda, H Miller, R S McLachlan
}

\begin{abstract}
Of 298 patients who had temporal lobectomies for intractable epilepsy, 4 (1.3\%) developed post-ictal psychosis for the first time after surgery. All were males of normal intelligence with no pre-operative psychiatric disorder. Psychosis followed both complex partial and generalised seizures. The psychotic symptoms showed polymorphic features. Right temporal lobectomy may increase the susceptibility to post-ictal psychosis in patients who are not seizure free after surgery, particularly in the first postoperative year.
\end{abstract}

(F Neurol Neurosurg Psychiatry 1993;56:277-279)

Chronic interictal psychoses of epilepsy have been studied extensively, but research in postictal psychotic states is relatively scant. $^{1-3}$ Post-ictal psychosis has a clear temporal relationship with seizure activity. A flurry of complex partial seizures which may or may not become secondarily generalised or a single prolonged seizure may precipitate a post-ictal psychosis. Spontaneous resolution is usual, but recurrence is common. The clinical picture is polymorphic with behavioural disturbance, delusions and/or hallucinations, with or without confusion.

There are several reports of paranoid or schizophrenia-like psychosis which developed de novo following surgical resection of one temporal lobe for intractable epilepsy, ${ }^{4}$ but these psychotic disorders did not relate to seizure activity. There are no reports of postictal psychosis appearing in individuals who have had surgery for epilepsy. Four such cases are described.

\footnotetext{
Department of Psychiatry, University of Western Ontario London

R Manchanda

Department of

Clinical Neurological

Services, University of

Western Ontario,

London

H Miller

R S McLachlan

Correspondence to:

Dr Manchanda, University

Hospital, Box 5339 ,

London, Ontario, Canada

London,

Received 31 March 1992

and in revised form

30 June 1992

Accepted 10 July 1992
}

Approximately 450 patients had neurosurgical intervention for intractable seizure disorders between 1974-90. A total of 298 patients had a temporal lobectomy for control of seizures. Of these, 4 patients developed a post-ictal psychosis after surgery in the absence of chronic interictal psychosis. All patients had continuous EEG recording during the psychosis. The hospital charts for these 4 patients were reviewed for the clinical information, EEG data and histology of the resected temporal lobes. Although no formal pre-operative psychiatric assessments were carried out, there was no history of previous psychiatric illness in these patients. One patient had compulsive personality traits. All 4 patients met the diagnostic criteria for postictal psychosis. ${ }^{1}$ Psychiatric ratings were obtained using the Syndrome Check List, a schedule derived from the Present State Examination (PSE) ${ }^{5}$ for retrospective evaluation of case records. A total of 38 syndromes can be recorded from 140 symptoms rated in the PSE. Each syndrome has a score, comprising the summed score of its constituent symptoms and a degree of certainty $(0, ?,+$, ++ ).

\section{Results}

Four of 298 patients (1.3\%) who had a temporal lobectomy developed a post-ictal psychosis. All four patients were males with normal intelligence, between the ages of 24 and 44, with a duration of epilepsy of 6 to 42 years (table 1). All patients had the onset of post-ictal psychosis post-operatively. None had evidence of interictal psychosis preoperatively or during post-operative follow up ranging from 3 to 15 years. None experienced post-ictal psychosis before surgery. It was not necessary for the seizures to generalise for psychosis to occur. As few as two focally originating seizures in the 24 hour period could precipitate a psychosis in two of the patients while in the other two, post-ictal psychosis appeared after a flurry of complex partial seizures progressing to secondary generalisation. There was a latency of 1 to 2 days before psychosis developed in two patients and it was present immediately after recovery from the seizures in the other two. The duration of psychosis was 1 to 8 days.

Right temporal originating seizures were recorded in 3 patients and the fourth was operated on the basis of interictal and other data. Interictal and ictal abnormalities were seen in the left temporal lobe in 2 patients 
Table 1 Clinical characteristics of four patients with post-lobectomy post-ictal psychosis

\begin{tabular}{|c|c|c|c|c|c|c|c|}
\hline $\begin{array}{l}\text { Case number } \\
\text { Sex }\end{array}$ & $\begin{array}{l}\text { Age at } \\
\text { seizure } \\
\text { onset; } \\
\text { at right } \\
\text { temporal } \\
\text { lobectomy } \\
\text { (years) }\end{array}$ & $\begin{array}{l}\text { Number of } \\
\text { psychotic } \\
\text { episodes }\end{array}$ & $\begin{array}{l}\text { Time } \\
\text { from } \\
\text { surgery } \\
\text { to episode }\end{array}$ & $\begin{array}{l}\text { Number of } \\
\text { precipitating } \\
\text { seizures; } \\
\text { type }\end{array}$ & $\begin{array}{l}\text { Psychosis } \\
\text { free } \\
\text { period } \\
\text { (days) }\end{array}$ & $\begin{array}{l}\text { Duration } \\
\text { of } \\
\text { psychosis; } \\
\text { (days) }\end{array}$ & $\begin{array}{l}\text { Clouding } \\
\text { during } \\
\text { psychosis }\end{array}$ \\
\hline 1 Male & $\begin{array}{l}18 \\
24\end{array}$ & 1 & 13 years & $\begin{array}{l}7 \text {; } \\
\text { grand mal }\end{array}$ & 2 & 1 & no \\
\hline $\begin{array}{l}2 \\
\text { Male }\end{array}$ & $\begin{array}{l}13 \\
29\end{array}$ & 1 & 4 months & $\begin{array}{l}2 ; \\
\text { complex }\end{array}$ & 1 & 7 & no \\
\hline $\begin{array}{l}3 \\
\text { Male }\end{array}$ & $\begin{array}{l}1 \frac{1}{2} \\
44\end{array}$ & 5 & $\begin{array}{l}6-15 \\
\text { months }\end{array}$ & $\begin{array}{l}2-7 ; \\
\text { at first } \\
\text { complex } \\
\text { partial, } \\
\text { later } \\
\text { grand mal }\end{array}$ & 0 & $4-8$ & no \\
\hline $\begin{array}{l}4 \\
\text { Male }\end{array}$ & $\begin{array}{l}33 \\
42\end{array}$ & 2 & $\begin{array}{l}9 \text { months, } \\
19 \text { months }\end{array}$ & $\begin{array}{l}2 \text {; } \\
\text { partial }\end{array}$ & 0 & 2 & yes \\
\hline
\end{tabular}

(table 2). The left hemisphere was dominant for speech in all four patients. All had a right temporal lobectomy which revealed mesial temporal sclerosis in 3 patients and normal tissue in one. Seizure frequency decreased, but sporadic seizures continued to occur in all 4 patients. The clinical and EEG features of these seizures suggested that they arose either from the right temporal resection border or the right frontal region. Patients 3 and 4 became seizure free eighteen months and 3 years post-operatively after antiepileptic medications were altered.

The features of the post-ictal psychosis are recorded on the Syndrome Check List of the Present State Examination. The ratings were made on their frequency of occurrence with a degree of certainty of + or ++ . Ratings were made conservatively and data expressed vaguely in the case notes were not included. Fifteen of 38 syndromes could be recorded in these cases. Although there were common features in some of these patients, no generalisations can be made regarding symptoms. Three patients had depressive delusions and hallucinations (1,2 and 4) and non-specific psychosis $(2,3,4)$. Two patients had nuclear syndromes, paranoid delusions and delusional moods (2 and 3). Simple depression was rated in two patients ( 2 and 4 ). Changed per-

Table 2 EEG changes in four patients with post-lobectomy post-ictal psychosis

\begin{tabular}{|c|c|c|c|}
\hline Case & $\begin{array}{l}\text { Preoperative } \\
\text { side of } \\
\text { temporal } \\
\text { a) spikes } \\
\text { b) seizures }\end{array}$ & $\begin{array}{l}\text { Post- } \\
\text { operative } \\
\text { interictal } \\
\text { EEG }\end{array}$ & $\begin{array}{l}\text { EEG } \\
\text { during } \\
\text { post-ictal } \\
\text { psychosis }\end{array}$ \\
\hline 1 & $\begin{array}{l}\text { a) Right } \\
\text { b) None recorded }\end{array}$ & $\begin{array}{l}\text { Independent } \\
\text { bitemporal } \\
\text { theta. }\end{array}$ & $\begin{array}{l}\text { Generalised delta; } \\
\text { occasional brief } \\
\text { bursts of } 2 \mathrm{~Hz} \text { sharp } \\
\text { and slow. }\end{array}$ \\
\hline 2 & $\begin{array}{l}\text { a) Bilateral } \\
\text { independent } \\
\text { b) } 7 \text { right; } \\
3 \text { left }\end{array}$ & $\begin{array}{l}\text { Right temporal } \\
\text { spikes. } \\
\text { Delta: right } \\
\text { temporal and } \\
\text { frontal; } \\
\text { occasional } \\
\text { left temporal. }\end{array}$ & $\begin{array}{l}\text { Spikes: sporadic right } \\
\text { temporal. Bitemporal } \\
\text { delta. }\end{array}$ \\
\hline 3 & $\begin{array}{l}\text { a) Bilateral } \\
\text { independent } \\
\text { b) } 3 \text { right, } \\
2 \text { bitemporal }\end{array}$ & $\begin{array}{l}\text { Right posterior } \\
\text { temporal delta. }\end{array}$ & $\begin{array}{l}\text { Diffuse theta } \\
\text { and delta. }\end{array}$ \\
\hline 4 & $\begin{array}{l}\text { a) Right } \\
\text { b) } 3 \text { right }\end{array}$ & $\begin{array}{l}\text { Right temporal } \\
\text { spikes. Right } \\
\text { temporal delta. }\end{array}$ & $\begin{array}{l}\text { Right temporal } \\
\text { spikes and } \\
\text { delta. }\end{array}$ \\
\hline
\end{tabular}

ception of time and organic impairment with confusion were seen in patient 4 . In addition, patient 1 had religious delusions and patient 4 had irritability, lack of energy and anxiety. All patients responded to neuroleptic medication (oral haloperidol) which was discontinued when the psychoses resolved.

\section{Discussion}

Although there are no prevalence studies of the condition, post-ictal psychosis, as such, is a rare disorder. Given the acute presentation, short duration of illness and possible nonadmission to hospital, it would be difficult to make any conclusions of its frequency. An estimate of $1.3 \%$ in patients undergoing temporal lobectomy in our series is at best tentative and may be an under-estimate as the cases reported are the ones that came to our attention. Conversely, a blatant psychosis as in these patients would probably not be missed since the majority of our patients are followed up at 6 monthly intervals for 2 years and yearly thereafter. As there are no other descriptions of post-ictal psychosis occurring after temporal lobe resection, we can only compare our findings with the literature on post-ictal psychosis in general.

The salient findings are as follows. All patients met the diagnostic criteria of Logsdail and Toone. ${ }^{1}$ Psychosis usually occurred after an exacerbation in seizure frequency. It was not necessary for seizures to generalise for psychosis to occur. All patients were males and had had right temporal lobectomy. The psychotic symptoms showed a variable rather than discrete pattern. Clinically, there was no difference between post-ictal psychosis and a post-operative postictal psychosis. The patients responded to treatment and had a good prognosis. None of these patients has developed a chronic interictal psychosis and none had pre-operative psychiatric illness.

In this series, as few as two focally originating seizures in a 24 hour period could precipitate psychosis. Early reports on post-ictal psychosis $^{67}$ emphasise the importance of grand mal seizures, usually in clusters, without a clinically focal onset. Levine ${ }^{7}$ noted 
frequent precipitation by alcohol or drug withdrawal and found that the interval between precipitating seizures and the psychosis was usually less than a day. In contrast, in 14 patients with post-ictal psychosis, secondary generalisation of complex partial seizures was common and that a post-ictal "lucid" non-psychotic interval of more than a day was usual. ${ }^{1}$ Two of our patients had such a "lucid" interval lasting 1 to 2 days supporting the latter finding.

In patients 1 and 3, the new occurrence of flurries of seizures may have contributed to increasing susceptibility to post-ictal psychosis. One of these as well as patient 2 had such flurries pre-surgically without psychosis suggesting that the surgery itself may have increased susceptibility to post-ictal psychosis. In case 1 and 2, flurries of seizures have subsequently occurred without psychosis. It is not clear why susceptibility to post-ictal psychosis has varied in these patients; it could be indicative of a transient period of increased susceptibility after temporal lobectomy, such as, that occurring for other types of psychopathology.$^{8}$ Stevens ${ }^{9}$ in a follow up of patients having temporal lobectomy notes a 6 to 12 month interval between the operative procedure and development or deterioration of psychopathology. She proposes aberrant reinnervation in projection sites of the damaged or removed medial temporal structures to explain post-surgical psychosis of the chronic type. Persistence of local epileptic activity could contribute to such a phenomenon as it stimulates anomalous sprouting and synaptic expansion. ${ }^{1011}$ Another explanation is that surgery was incidental and psychosis could have occurred anyway in these patients. That could most easily be argued for patient 1 who developed psychosis 13 years post-operatively.

Logsdail and Toone ${ }^{1}$ reported that EEGs taken during psychosis did not show ictal activity and that precipitating seizures commonly occur in clusters of about 3 . So et $a l^{2}$ also demonstrated absence of ictal activity during post-ictal psychosis in a patient monitored by bilateral depth and epidural electrodes. Savard et $a l^{3}$ described 9 cases and in 7 of these the seizure flurry was precipitated by withdrawal of antiepileptic drugs during investigation with a view to surgical treatment of epilepsy. EEGs during the psychotic period in our patients revealed no ongoing seizure activity. In 3 patients, the findings were the same as in previous interictal recordings and in 1 carried out within hours of the seizure a mild post-ictal change was seen. All patients remained on at least 2 antiepileptic drugs after surgery. No alteration in drug therapy had been made within the 2 months before post-ictal psychosis occurred.

All four patients were left hemisphere dominant for speech and had right temporal lobectomies. The right sided preponderance is reminiscent of that found by Levine and Finkelstein ${ }^{12}$ in their eight patients with right posterior cerebral hemisphere stroke or trauma followed by psychosis; seven of these patients had seizures probably arising from the right hemisphere and in two, the psychosis was both post-ictal and transient. In a recent report of 6 consecutive patients with chronic post-operative psychosis referred for psychiatric assessment after temporal lobectomy, all were males who had surgery on the right hemisphere. ${ }^{13}$ This is strikingly similar to our findings. Furthermore, right sided temporal surgery is associated with nearly three times the frequency of subsequent psychosis than surgery to the left temporal lobe. ${ }^{4}$

The association of schizophreniform psychosis with dominant left temporal lobe epilepsy $^{14}$ has been a controversial topic with support from some studies ${ }^{15}$ and no support from others. ${ }^{16}$ The finding that removal or destruction of the right temporal lobe can result in transient or permanent psychosis, particularly when seizures continue to appear from the right hemisphere suggests that, in contrast to increased activity in the left temporal lobe, decreased activity or hypofunction of the right temporal lobe may play a role in the pathogenesis of psychotic disorders. Further studies of post-operative psychiatric states may help clarify these issues.

1 Logsdail SJ, Toone BK. Post-ictal psychosis: a clinical and phenomenological description. Br $\mathcal{f}$ Psychiatry 1988; 152:246-52.

2 So NK, Savard G, Andermann F, Olivier A, Quesney LF. Acute postictal psychosis: a stereo EEG study. Epilepsia 1990;31:188-93.

3 Savard G, Andermann F, Olivier A, Remillard GM Postictal psychosis after partial complex seizures: a multiple case study. Epilepsia, 1991;32:225-31.

4 Trimble MR. The psychoses of epilepsy. NY, Raven Press, 1991.

5 Wing JK, Cooper JE, Sartorius N. The measurement and classification of psychiatric symptoms. London: Cambridge University Press, 1974.

6 Clark RA, Lesko JM. Psychosis associated with epilepsy. Am f Psychiatry, 1939;96:595-607.

7 Levin S. Epileptic clouded states: a review of 52 cases. $\mathcal{f}$ Nerv Ment Dis 1952;116:215-25.

8 Fenwick PBC. Long-term psychiatric outcome after epilepsy surgery. In: Luders HO, ed. Epilepsy surgery. NY: Raven Press, 1992:647-52.

9 Stevens JR. Psychiatric consequences of temporal lobectomy for intractable seizures: a $20-30$ year follow up of 14 cases. Psycholog Med 1991;20:529-45.

10 Sutula T, Xiao-Xian H, Cavazos J, Scott G. Synaptic reorganization in the hippocampus induced by abnorreorganization in the hippocampus induced by ab
mal functional activity. Science 1988;239:1147-50.

11 Geinisiman Y, Morell FR, de Toledo-Morrell L Perforated synapses on double-headed dendritic spines: Perforated synapses on double-headed dendritic spines:
a possible structural substrate of synaptic plasticity. a possible structural subs
Brain Res 1989;480:326-9.

12 Levine DN, Finkelstein S. Delayed psychosis after right temporoparietal stroke or trauma: relation to epilepsy Neurology 1982;32:267-73.

13 Mace CJ, Trimble MR. Psychosis following temporal lobe surgery: a report of six cases. $f$ Neurol Neurosurg Psychiatry 1991;54:639-44.

14 Flor-Henry P. Psychosis and temporal lobe epilepsy. Epilepsia 1969;10:363-95.

15 Perez M, Trimble M R. Epileptic psychosis: an evaluation of PSE profiles. Br $\mathcal{f}$ Psychiatry 1985;146:155-164.

16 Parnas J, Korsgaard S. Epilepsy and psychosis: a review. Acta Psychiat Scand 1982;66:89-99. 